Bulletin of Taras Shevchenko National University of Kyiv.

Public Administration, 2(14), 25-28.

UDC 351

https://doi.org/10.17721/2616-9193.2021/14-5/6

Alex Sherm, Doctor of Business Administration, Professor Graduate Program Chair at Westcliff University, Irvine, California, USA e-mail: asherm@iaula.edu

\title{
BUILDING AND LEADING TEAMS: UNIVERSITY PERSPECTIVE ON EDUCATING STUDENTS AND DEVELOPING PROFESSIONALS IN PUBLIC ADMINISTRATION AND BUSINESS ORGANIZATIONS
}

One of the key principles of university preparation and development of the new generation of future practitioners and scholars in the field of public and business administration is team forming, development, leading, synergizing, and managing methodologies. The paper discusses increasing the role of University professors' leadership in online interactive team learning in the post-pandemic era, team-building strategies in online team learning, team synergy as a core key to teams' success, its concepts and elements, as well as evolving from conflict to synergy.

Keywords: Public Administration, Leading Teams, Business Organizations, University Perspective.

\section{Increasing the Role \\ of University Professors' Leadership \\ in Online Interactive Team Learning in the Post-Pandemic Era}

The modern business world has placed great responsibility in hands of leaders by calling for the formation of multi-diversity teams composed of representatives of various generations, cultures, origins, education, and professional experiences. Also, ambitious goals and increasing business dynamics, as well as shorter deadlines for projects completion become, more than ever, an immensely complex task to integrate, align and synergize human capital.

Today's leaders face and need to overcome many challenges during developing their teams, concepts and techniques that support leadership when exercised in working groups. This is why we pay serious attention during development of the principles for Public Administration and Business Administration degree granting programs (on undergraduate, graduate and doctoral levels), as well as certificate courses to teams' forming, development, leading, synergizing, and managing towards success.

The very first question is if leaders are properly trained to act in challenging situations? Both processes - training and real-life team leadership are inevitably filled with many uncertainties and even conflicts. The resulting disarray makes a leader often unprepared to deal with numerous unique variables causing many difficulties in integrating people and developing the maturity of the teams. It is obvious and important that a good leadership is set by an example. The example can be presented and exist in different facets, but it definitely has to be there.

One of the fundamental elements of educating our undergraduate, graduate, and doctoral students, as well as lifetime development of practitioners for public and business administration sectors is team learning, and, accordingly, team building methodology as an organic part of leadership process, which includes teams' forming/building, operating, effective performance, and achieving expected/required highest learning outcomes.

As our analyses of the practice of team building (as a part of the leadership process), show that the rule of observing and analysing, first of all negative examples rather than good/positive ones, plays a significant role in finding the best ways towards leadership success. This is why, while educating our graduate and doctoral students, we emphasize the importance of being aware of this very important aspect.
University professors, as leaders of the entire mission and the processes of team learning, are obligated and responsible for driving teams in a dynamic and empowering way. Nowadays, one of the imperative parts of professors' preparation and mission is team building and their leadership in both virtual (online) and traditional learning environments. Due to the Covid-19 pandemic, overwhelming number of universities urgently switched to online learning programs and it is worth emphasizing that even in post-Covid-19 era, online learning modality in virtual interactive environment may remain and become the main one.

Since online interactive modality (1) and team learning (2) are among the main pillars of the modern higher education, university professors must be, accordingly, initially trained, further periodically developed and become well versed in team building and leadership of entire processes, in particular, methodology and practical implementation of team learning. In particular, they should be able to practically build students' learning teams, teach them the art of team learning, including building teams, processes of team learning, as well as ways and benchmarks for deep enhancement of team's results and outcomes.

As the result, our university professors are dealing with the triune task, which includes the following three elements:

1. Professors' preparation and training on: team building, team learning leadership/administration.

2. Building, leading, and managing student teams during each course of study.

3. Teaching students how to build, lead, and administer teams in the real life in public administration and business organizations and companies.

Another important element in educating our graduate, and doctoral students is experiential learning as the process of "learning through reflection on doing" from professors and/or top leaders. Very important part of this is learning experiences and lessons of failures of various small and large public administration and non-profit organizations, as well as business, startups, small and large well-established companies. And, studying benchmarks and, accordingly, performing permanent analyses help our students to be prepared for more efficient implementation of best practices and innovative ways of administration. 


\section{Team-Building Strategies}

in Online Team Learning: Benchmarks

As the result of comprehensive analyses of the numerous types of team-building strategies the following strategies were determined as the most effective ones for further implementation as the solution for our triune task: professors' preparation and training, student team building, and teaching students on team building (Villanova University, 2020).

\section{Strategy One: Personality-Based Team Building}

As the initial step, the personality test is performed. It is based on Myers-Briggs Type Indicator (MBTI) classification of various, more than one-dozen, personalities of both professors and students: their own strengths, weaknesses, and opportunities. Each personality (introverted or extroverted) may benefit the team by contributing to the new ideas and accomplishments.

\section{Strategy Two: Activity-Based Team Building}

The core of this strategy is performing a series of challenging tasks designed to take team members out of their comfort zones allowing them to learn how to work together and trust each other.

\section{Strategy Three: Skills-Based Team Building}

Team members participate in express trainings towards developing important team skills, including negotiations, conflict resolution, providing constructive feedback and etc. Those newly-acquired skills are very useful for immediate boosting team performance.

\section{Strategy Four: Problem Solving-Based Team Building}

Team member analyse their internal team dynamics, discover problems within the team (performance, morale, communication and etc). This set of skills helps to narrow in on issues and work towards resolutions.

\section{Strategy Five: Knowledge Sharing}

Team members' knowledge is exchanged among each other enhancing team's capability, effectiveness, interdisciplinary potential, and allowing achievement of much higher synergetic results.

The research shows (Zaccaro, Rittman, \& Marks, 2002) that the usage of those five strategies described above enhance leader's performance results in the following way:

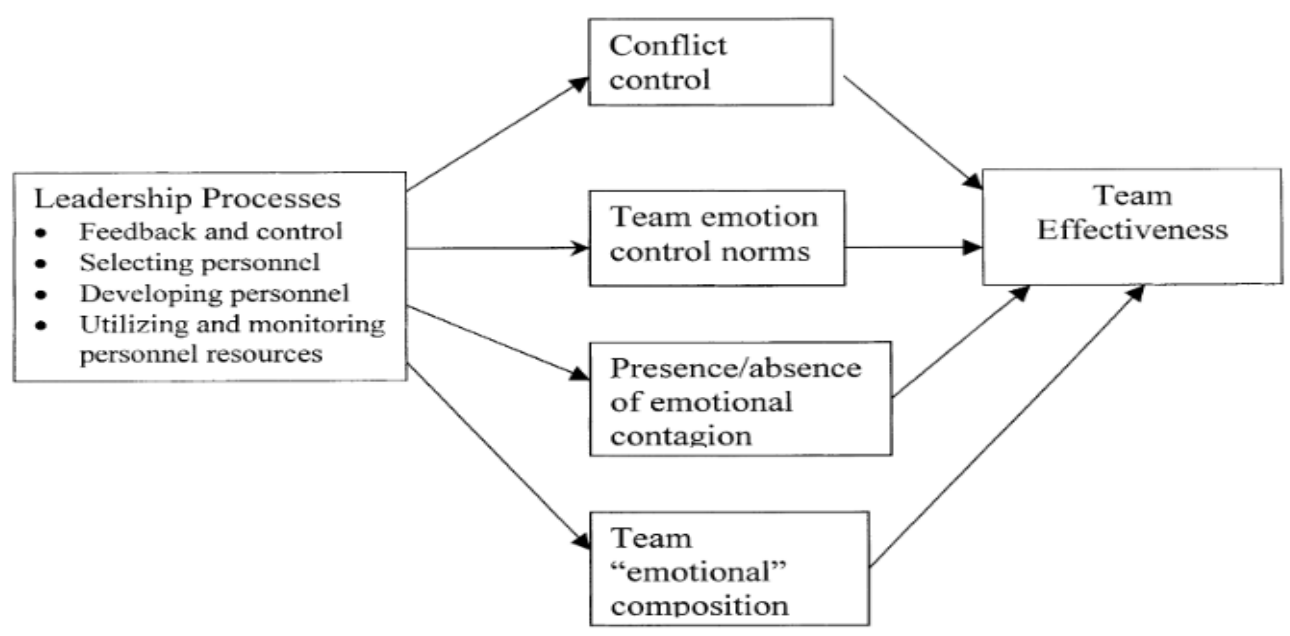

Figure 1. Influence of leader performance functions on team effective processes

Source: Zaccaro, Rittman, \& Marks, 2002.

\section{Team Synergy as a Core Key to Teams' Success}

The best understanding of synergy's concepts stems from chemistry, which explains that behavior of the separated atoms cannot explain the behavior of all of them interconnected in the molecules. Chemical theory named "...this principle as synergy, a form of collective transmutation that allowed for endless research and innovation. Forbes defines the potential for team synergy as the combination of common interests, common values, and complementary talents. In modern organizational theory, synergy means much more than "working together." Synergy is actually a systemic principle that explains how a team's collective performance is unpredictable based solely on its member's individual performances. Therefore, a team's collective performance can be either better or worse than the sum of its members' individual performances." (Romero, 2015).

Synergy not necessary brings a positive result of the team's work, since there could be two types of synergy: positive (organizational success) and negative (organizational failure). Those very important polar characteristics of the synergy directly relate to the quality and success of the team. In fact, bringing into a team the "wrong person" can become an ignition of its devastation. This is why hiring the "wrong person" maybe worse than not hiring the right person.

Synergy as the important phenomenon of team work has its own elements and concepts. There are numerous classifications of synergy's elements and concepts. Applying to our research and development of the university perspective on educating and developing public administration and business students and professionals we suggest the following ones:

\section{Concepts and Elements of Teams' Synergy}

Our research results show that among many wellknown concepts and elements of synergy revealed by numerous researchers, the most instrumental ones are:

\section{Concepts of Teams' Synergy (4Cs)}

1. Common interests

2. Common values 
3. Complementary talents

4. Complementary knowledge sharing

When team members (within learning teams, organizations' teams, and etc.) share common interests and common values, they mobilize their creativity, build long-term beneficial cooperation, maximize their energy and dedicate it towards achieving the same mutual goal(s).

According to Forbes' research: "... people who share the values of humility, honesty, trust, and discipline achieve the highest synergies. ... every team's ideal portfolio of talents is masterfully summarized in Dr. Ichak Adizes's famous PAEl model. PAEI stands for Producer, Administrator, Entrepreneur, and Integrator. Not one person will have all four talents. ... Everyone needs help and teamwork is based on team members helping each other." (Ibid). When team members possess complementary talents, they become truly capable for achieving expected outcomes.

\section{Elements of Teams' Synergy (8Cs)}

- C1. Consciousness

- C2. Communication

- C3. Cooperation

- C4. Coordination

- C5. Convergence

- C6. Conviction

- C7. Companionship

- C8. Creativity

\section{C1. Consciousness}

Consciousness is the concept that integrates the perception and identification of the individual with the three most important elements of organizational identity: mission, vision, and values. Team members work with more enthusiasm when they understand that their individual tasks and the work of his staff contribute to a higher purpose. Without awareness of the mission, vision, and organizational values, all routine work seems disjointed and meaningless, causing distress and dissatisfaction that threaten the integrity of the group.

\section{C2. Communication}

Communication is the concept that expresses the ability of the team to deal with the information relevant to the implementation of the methods and goals. The importance of communication for the synergy of the group is in the dialogue which means "stream of meaning". Facilitating communication supports organizational identity (mission, vision, and values) and its significance.

\section{C3. Cooperation}

Cooperation is the concept that expresses the power to "operate together" (co-operate). A team that fully cooperates, works faster, generates fewer costs and gets better outcomes.

\section{C4. Coordination}

Coordination is the concept that expresses the shared use of power and responsibility. It is the right and duty of all team members. The power and responsibility not centred on the leader or even a member fosters the team's maturity and self-management by promoting discipline necessary for the efficient execution of tasks.

\section{C5. Convergence}

Convergence is the concept that expresses the interdependence among the goals in the various cells and levels of the organization. After achieving individual goals the convergence contributes to the achievement of the mutual goals of the team, and the achievement of the mutual goals of the team contributes to the achievement of organizational goals. Conflicts and disagreements, when to arise, are quickly administered by the team, so that both individual results as not compromised.

\section{C6. Conviction}

Conviction is the concept that expresses the subjective value credit deposited between team members. Without conviction, the communication becomes shallow, concealed and, consequently, the "spirit of teamwork" is weakened.

\section{C7. Companionship}

The Companionship is the concept that expresses the behaviour and zeal among team members.

Unlike the friendship that is based on mutual affection, companionship is a behaviour that is independent of personal preferences. It is aimed at the well-being of all to achieving the goals of the team. The lack of companionship with a group creates an inhospitable psychological environment, leading participants to the feeling of insecurity that reduce productivity, creativity and commitment to cohesion.

\section{C8. Creativity}

Creativity is the concept that expresses the manifestation of the power transformer and evolutionary renewal of a team. When it is given to all the right to contribute ideas, creates an exciting atmosphere that increases the motivation for participation. Moreover, creativity is predecessor of innovations followed by new business strategies.

\section{Teams' Evolving from Conflict to Synergy}

According to (Melita Prati, 2003), the conflict arises when there is a disagreement resulting from information and different personal preferences "while synergy is when" the result of the group is better than individual results". We realize, therefore, that synergy is the real modus operandi of a team as it provides results that cannot be achieved individually, but as foster synergy in a team.

As American President Ronald Reagan said - "Peace is not absence of conflict, it is the ability to handle conflict by peaceful means. I've always believed that a lot of the troubles in the world would disappear if we were talking to each other instead of about each other". - Ronald Reagan (Brandon, 2014).

We strongly believe that described elements and concepts Synergy are reliable tools for prevention conflicts within the teams.

\section{Conclusion}

Teams' forming, development, leading, synergizing, and managing methodologies are not only a mandatory chapter of universities' public and business administration educational programs, but a philosophy and a guiding principle of preparation and development of both educators and future practitioners. The effectiveness of this mission will directly affect quality of a new generation of public and 
business organizations leaders and their all-embracing results and success.

References

Brandon, John (2014, October, 23) 48 All-Time Best Quotes on Facing Workplace Conflicts that workplace conflict is making you feel stressed. Take some time to think it through and listen to the masters. Retrieved from https://www.inc.com/john-brandon/48-all-time-best-quotes-on-facing workplace-conflicts.html.

Fisher, K. (1999). Leading self-directed work teams. McGraw Hill Professional.

Melita Prati, L. D. (2003). Emotional intelligence, leadership effectiveness, and team outcomes. The International Journal of Organizational Analysis, 11(1), 21-40.

Вісник Київського національного університету імені Тараса Шевченка. Державне управління, 2(14), 25-28.

https://doi.org/10.17721/2616-9193.2021/14-5/6

Алекс Шерм, доктор ділового адміністрування, проф.

Університет Весткліфа, Ірвін, Каліфорнія, США

e-mail: asherm@iaula.edu

\section{СТВОРЕННЯ I КЕРУВАННЯ КОМАНДАМИ: \\ ПЕРСПЕКТИВИ УНІВЕРСИТЕТІВ В ОСВІТІ СТУДЕНТІВ ТА РОЗВИТКУ ПРОФЕСІОНАЛІВ У ПУБЛІЧНОМУ УПРАВЛІННІ І БІЗНЕС-ОРГАНІЗАЦІЯХ}

Одним із ключових принципів університетської підготовки й розвитку нового покоління майбутніх практиків й учених у галузі державного і публічного адміністрування є методології формування, розвитку, лідерства, синергізму й управління командою. У статті проаналізовано підвищення ролі керівництва університетських професорів в інтерактивному командному онлайн-навчанні в постпандемічну епоху, стратегї побудови команди в онлайн-командному навчанні, командна синергія як базовий ключ до успіху команди, а також їі концепції та елементи, як еволюція від конфлікту до синереії.

Ключові слова: державне управління, провідні команди, бізнес-організації, університетська перспектива.
Romero, Luis E. (2015, Dec 1). The Ultimate Guide to Team Synergy. Retrieved from https://www forbes.com/sites/luisromero/2015/12/01/theimate-guide-to-team-synergy/?sh=579fbf252f52.

(2020, March 17). 4 Types of Team-Building for the

Zaccaro, S. J., Rittman, A. L., \& Marks, M. (2001). Team leadership.

Received: April 05, 2021

Published: June 08, 2021 eadership/4-team-building-tips-for-the-modern-business/. 